\title{
Yield and quality of winter oilseed rape (Brassica napus L.) seeds in response to foliar application of boron
}

\author{
Krzysztof J. Jankowski ${ }^{1}$, Mateusz Sokólski ${ }^{1}$, Bogdan Dubis ${ }^{1}$, Sławomir Krzebietke ${ }^{2}$, Piotr Żarczyński ${ }^{2}$, Paweł Hulanicki ${ }^{1}$ \\ Piotr S. Hulanicki ${ }^{3}$, \\ ${ }^{1}$ Department of Agrotechnology, Agricultural Production Management and Agribusiness, \\ University of Warmia and Mazury in Olsztyn, Oczapowskiego 8, 10-719 Olsztyn, Poland \\ ${ }^{2}$ Department of Agricultural Chemistry and Environmental Protection, University of Warmia and Mazury in Olsztyn, \\ Oczapowskiego 8, 10-719 Olsztyn, Poland \\ ${ }^{3}$ Kazgod Ltd, Wierzbowa 7, 05-870 Błonie, Poland \\ email: krzysztof.jankowski@uwm.edu.pl
}

\begin{abstract}
This paper presents the results of a 3-year field experiment conducted on soil with moderate levels of boron (B) in north-eastern Poland to determine the influence of foliar application of $B\left(0,150\right.$ and $\left.300 \mathrm{~g} \mathrm{ha}^{-1}\right)$ on the yield components, yield, mineral composition, nutritional value and feed value of winter oilseed rape seeds. Foliar application of $B$ at the beginning of bud formation in winter oilseed rape increased seed yield by $0.19(3 \%)$ at the lower B fertilization level to $0.26 \mathrm{Mg} \mathrm{ha}^{-1}(4 \%)$ at the higher B fertilization level. The observed increase in the yield of winter oilseed rape seeds in response to foliar application of B can be attributed to this micronutrient's positive influence on seed production in siliques. Foliar fertilization with $\mathrm{B}$ increased $\mathrm{B}$ content and decreased $\mathrm{Zn}$ and Fe levels in the seeds of winter oilseed rape. When B fertilizer was applied at the rate of 150-300 $\mathrm{g} \mathrm{ha}^{-1}$, the N and $\mathrm{Ca}$ content of the evaluated seeds increased. The fertilizer improved the nutritional value (crude fat content, fatty acid concentrations) of seeds, but deteriorated their feed value (total protein content, acid detergent fiber concentrations, neutral detergent fiber concentrations, quantitative and qualitative composition of glucosinolates).
\end{abstract}

Key words: Brassica crops, yield, nutrients, fat, protein, fiber, glucosinolate

\section{Introduction}

According to estimates, $88 \%$ of arable land in Poland is deficient in boron (B). The above can be attributed to the fact that Podzoluvisols and Luvisols, formed mainly from Devonian and Carboniferous sediments, account for around $25 \%$ of all soils in the country. Those types of soil, which cover also extensive regions in Scandinavia and Central-Eastern Europe (Shorrocks 1997), are generally highly deficient in B. For this reason, the effectiveness of B fertilization may be high in those regions, in particular in plant species that readily accumulate this micronutrient.

Boron plays an important physiological role in the formation and structural integrity of the cell wall by crosslinking rhamnogalacturonan II (RG-II) (O'Neill et al. 2004). Graminaceous species with lower levels of RG-II in cell walls have a lower demand for B and are less sensitive to B deficiency than dicotyledons (Chormova et al. 2014). Only two dicotyledon families were found to be sensitive to B deficiency - Brassicaceae (Brassica spp. and Raphanus spp.) and Chenopodiaceae (Beta spp.) (Shorrocks 1997). Rapeseed (Brassica napus L.), in particular its high-yielding winter varieties, is a Brassica crop with the highest B uptake (Camacho-Cristóbal et al. 2008, Zhang et al. 2014). The "flowering without seed setting" syndrome in B. napus was first reported in China in the 1970s, and was soon proven to be caused by B deficiency (Wang et al. 2007). In the Polish climate, canola varieties of winter oilseed rape with a low content of erucic acid and glucosinolates (GLS) use around $145-290 \mathrm{~g} \mathrm{~B} \mathrm{ha}^{-1}$ to produce 3.5-5.3 $\mathrm{Mg} \mathrm{ha}^{-1}$ seeds and 4.4-7.1 $\mathrm{Mg} \mathrm{ha}^{-1}$ straw (Bowszys 2001).

Boron is required for the healthy growth of rapeseed plants from field emergence to full generative development (Grzebisz 2008). The average weight of one seed of $B$. napus is estimated at 3 to $6 \mathrm{mg}$, which limits the quantity of mineral nutrient reserves. Elements such as $\mathrm{K}, \mathrm{P}, \mathrm{S}, \mathrm{Mg}, \mathrm{Fe}, \mathrm{Mn}$ and $\mathrm{Zn}$ are accumulated mainly in unfolded cotyledons, and the seed coat contains predominantly Ca, Cu, Mo and B (Eggert and Wirén 2016). Nutrients stored in cotyledons are rapidly transported to roots to support their development during germination, whereas minerals accumulated in the seed coat are released and probably reabsorbed by developing roots (Zhao et al. 2012). A higher B content of seeds contributes to growth, increased water uptake and nutrient accumulation during germination. Root length and biomass production increase steadily in initial stages of rosette formation under exposure to growing levels of B (Eggert and Wirén 2016). The role of B extends beyond the cell wall structure, and the discussed element contributes to water retention in tissues (Wimmer and Eichert 2012). 
In a B deficiency,the disruption in water relations can be attributed to aquaporin-line channels, some of which are regulated by this micronutrient and transport boric acid and water (Reid 2014). Boron fertilization also intensifies the initial development of plants (Brown et al. 2002). Boron's stimulatory effect on the growth of rapeseed seedlings is linked with a higher content of other nutrients, mostly N (Brown et al. 2002), Ca and Mg (Liu et al. 2009), as well as K, S and $\mathrm{P}$ (Eggert and Wirén 2016) in plants.

In growing B. napus plants, B deficiency is manifested by inhibited root growth (roots turn brown and stop growing). The first symptoms on leaves are generally observed two days later. Leaf development is inhibited, leaves turn dark green and, eventually, purple. In the most severe cases, those changes can lead to tissue necrosis (Huang et al. 1996, Xu et al. 2001). Rapeseed plants are most sensitive to B deficiency during flowering because this micronutrient is essential for pollen production (Xu et al. 2001).

Yang et al. (2009) demonstrated that B fertilization of rapeseed can intensify the transport of photosynthesis products from the pericarp to seeds, which increases seed yield (Krauze et al. 1991, Bowszys 2001, Xu et al. 2001, Yang et al. 2009, Varenyiova and Ducsay 2014, Ma et al. 2015, Sienkiewicz-Cholewa and Kieloch 2015) and improves the nutritional and feed value of seeds (Krauze et al. 1991, Bowszys 2001, Malhi et al. 2003, Eggert and Wirén 2016).

In the last decade, the area under rapeseed increased at the rate of 1 million ha year ${ }^{-1}$ around the world to reach around 36 million ha in 2014 (FAOSTAT 2016). The economic significance of Brassica oilseed crops can be attributed to their role in global food security. Cereals have a $40-60 \%$ share of the human diet, but in highly industrialized countries, attempts have been made to increase the consumption of vegetable oils at the expense of cereal products (Glover et al. 2010). Many plant species of the family Brassicaceae are also excellent sources of protein in animal nutrition. The processing suitability of rapeseed used in the food and feed industries is determined not only by the nutritional value of seeds, but also by the content of biologically active compounds that are commonly found in plants of the family Brassicaceae. The use of oil from Brassica crops for human consumption is limited by its fatty acid profile (mainly the presence of erucic acid), oxidative stability, and the content of tocochromanols, phytosterols and polyphenols (Przybylski 2011). The suitability of fat-free seed residues for feed production is limited by the content of GLS, mainly alkenyl GLS, which are antinutritional factors (Verkerk et al. 2009, Przybylski 2011). Glucosinolate levels are determined mostly by genetic factors (variety) (Przybylski 2011), but the qualitative traits of a given rapeseed variety can be considerably influenced by the applied agricultural practices, mainly fertilization, the most important yield-related factor (Jankowski et al. 2015).

Boron fertilization increases the crude fat content of oilseed rape seeds (Krauze et al. 1991, Bowszys 2001, Yang et al. 2009, Öztürk et al. 2010, Varenyiova and Ducsay 2014, Sienkiewicz-Cholewa and Kieloch 2015) and improves the quality of rapeseed oil by increasing the concentrations of nutritionally important monounsaturated fatty acids (MUFAs) and polyunsaturated fatty acids (PUFAs) (Krauze et al. 1991, Yang et al. 2009). Boron fertilization has a varied influence on the total protein content of seeds in Brassica crops (Bowszys 2001, Malhi et al. 2003, Nadian et al. 2010, Öztürk et al. 2010). The above can be largely attributed to the role played by B in the growth and differentiation of tissues, functioning of plasma membranes, regulation of enzyme activity, carbohydrate metabolism (Matoh 1997), uptake and metabolism of N (Ruiz et al. 1998). Boron generally increases $\mathrm{N}$ accumulation in the seeds of winter oilseed rape, thus enhancing their feed value (Krauze et al. 1991, Jankowski et al. 2016). Yang et al. (2009) demonstrated that B fertilization can substantially lower GLS levels in the seeds of oilseed rape and improve their feed value.

The availability of B to plants is determined by soil properties, weather conditions and the applied agricultural treatments. Boron is most available in soils with acidic $\mathrm{pH}$ and high moisture content. Plants grown in alkaline soils or heavily limed acidic soils are less likely to absorb B. Soil drying can also significantly impair B availability to plants (Sienkiewicz-Cholewa 2005), in particular in soils that are deficient in this element. In a field study (Sienkiewicz-Cholewa 2005) carried out by the IUNG-PIB (Institute of Soil Science and Plant Cultivation - National Research Institute), $88 \%$ of the analyzed Polish production fields sown with rapeseed were deficient in B. Low levels of B were also noted in plants harvested from 65\% of Polish farms (Sienkiewicz-Cholewa 2005).

Boron fertilizers can minimize B deficiency in soil. It should be noted, however, that B is a non-renewable mineral resource that can exert a negative impact on the environment when applied in excessive quantities (Zhang et al. 2014). Boron toxicity exerts different effects on various processes in vascular plants by altering metabolism, inhibiting the division of root cells, lowering the content of leaf chlorophyll, decreasing photosynthetic rates and lowering lignin and suberin concentrations (Camacho-Cristóbal et al. 2008). Cereals are particularly sensitive to a high content of B in soil (Camacho-Cristóbal et al. 2008, Chormova et al. 2014). In Brassicaceae and Chenopodiaceae species that readily assimilate $B$, fertilization of soils with $B$ can lead to toxic concentrations of this micronutrient in successive crops (mostly cereals in Europe). The optimal B content of soil occupies a very narrow range of values 
between deficiency and phytotoxicity (Camacho-Cristóbal et al. 2008, Grzebisz 2008, Hänsch and Mendel 2009, Öztürk et al. 2010, Deora et al. 2014). Foliar application of B could be an effective and precise method for meeting the nutritional demands of plants (Jankowski et al. 2016), and it is a safer fertilization technique for successive crops (Grzebisz 2008).

The aim of this study was to determine the influence of foliar application of B (BBCH 50-55) on yield components, yield and mineral composition, nutritional value (crude fat content, fatty acid concentrations) and feed value (total protein content, acid detergent fiber (ADF) concentrations, neutral detergent fiber (NDF) concentrations, quantitative and qualitative composition of GLS) of seeds in high-input production of winter oilseed rape.

\section{Materials and methods}

\section{Field experiment}

A field experiment investigating winter oilseed rape was conducted in 2012-2015 at the Agricultural Experiment Station in Bałcyny ( $53^{\circ} 42^{\prime} \mathrm{N}, 19^{\circ} 51^{\prime} \mathrm{E}$, north-eastern Poland). Boron fertilizer was applied to the leaves of winter oilseed rape in spring at the rate of: (i) $0 \mathrm{~g} \mathrm{ha}^{-1}$ (control), (ii) $150 \mathrm{~g} \mathrm{~B} \mathrm{ha}^{-1}$ (BBCH 50), and (iii) $300 \mathrm{~g} \mathrm{~B} \mathrm{ha}^{-1}$ (150 $\mathrm{g} \mathrm{B} \mathrm{ha}^{-1}$ in $\mathrm{BBCH} 50$ and $150 \mathrm{~g} \mathrm{~B} \mathrm{ha}^{-1}$ in $\mathrm{BBCH} 55$ ). Boron was applied in the form of boron ethylamine.

The experiment had a complete randomized block design with three replications. Plot size was $15 \mathrm{~m}^{2}(1.5 \times 10)$. Each year, the experiment was established on Haplic Luvisol developed from boulder clay (IUSS Working Group WRB 2006). The soil had a slightly acidic $\mathrm{pH}$ ranging from 5.36-6.51. Soil nutrient levels were as follows: $1.02-$ $2.06 \% \mathrm{C}_{\text {org }}, 56-72 \mathrm{mg} \mathrm{P} \mathrm{kg}{ }^{-1}, 104-133 \mathrm{mg} \mathrm{K} \mathrm{kg}^{-1}, 49-63 \mathrm{mg} \mathrm{Mg} \mathrm{kg}^{-1}, 3.8-8.9 \mathrm{mg} \mathrm{kg}^{-1}, 0.48-0.52 \mathrm{mg} \mathrm{B} \mathrm{kg}^{-1}, 1.9-2.7$ $\mathrm{mg} \mathrm{Cu} \mathrm{kg}{ }^{-1}, 8.4-14.4 \mathrm{mg} \mathrm{Zn} \mathrm{kg}^{-1}, 131-184 \mathrm{mg} \mathrm{Mn} \mathrm{kg}^{-1}$, and 2100-2450 mg Fe kg-1. The content of $\mathrm{C}_{\text {org }}$, macronutrients $(P, K, M g$,$) , micronutrients (B, C u, Z n, M n, F e)$ and $p H$ was determined in the $0-30 \mathrm{~cm}$ soil horizon before the experiment. The $\mathrm{C}_{\text {org }}$ content of soil was determined by the Kurmies method (UV - 1201V spectrophotometer, Shimadzu Corporation Kyoto, Japan). Soil pH was determined with a digital pH meter with temperature compensation at $20^{\circ} \mathrm{C}$ in deionized water and in $1 \mathrm{~mol} \mathrm{I}^{-1} \mathrm{KCl}$. Plant-available $\mathrm{P}$ and $\mathrm{K}$ were measured by the Egner-Riehm method using $3.5 \mathrm{M}$ ammonium lactate acetic acid buffered to $\mathrm{pH} 3.75$ as extracting solution. Phosphorus was determined by the vanadium molybdate yellow colorimetric method (UV - 1201V spectrophotometer, Shimadzu Corporation Kyoto, Japan), and $\mathrm{K}$ - by atomic emission spectrometry (AES) (BWB Technologies UK Ltd. Flame Photometers). The content of plant-available $\mathrm{Mg}$ after extraction in $0.0125 \mathrm{~mol} \mathrm{I}^{-1} \mathrm{CaCl}_{2}$ was measured by atomic absorption spectrometry (AAS) (AAS1N, Carl Zeiss Jena, Germany). The content of B in soil was determined colorimetrically (UV - 1201V spectrophotometer, Shimadzu Corporation Kyoto, Japan), and the content of the remaining micronutrients ( $\mathrm{Cu}, \mathrm{Zn}, \mathrm{Mn}, \mathrm{Fe}$ ) - by AAS (AA-6800, Shimadzu Corporation Kyoto, Japan) after extraction in $1 \mathrm{~mol} \mathrm{l}^{-1} \mathrm{HCl}$. The content of was determined by nephelometry after extraction in acetate buffer (Shimadzu UV $1201 V$ spectrophotometer, Shimadzu Corporation Kyoto, Japan).

The preceding crops were cereals and legumes grown for green fodder. Before sowing, plots were fertilized with $30 \mathrm{~kg} \mathrm{~N} \mathrm{ha}^{-1}$ (urea, N 46\%), $35 \mathrm{~kg} \mathrm{P} \mathrm{ha}^{-1}$ (granular triple superphosphate, P 20\%) and $100 \mathrm{~kg} \mathrm{~K} \mathrm{ha}^{-1}$ (potassium chloride, $\mathrm{K} 50 \%$ ). In spring, soil was fertilized with $180 \mathrm{~kg} \mathrm{~N}^{-1}$ (ammonium nitrate, N 34\%) in two applications of $120 \mathrm{~kg} \mathrm{ha}^{-1}$ (BBCH 30) and $60 \mathrm{~kg} \mathrm{ha}^{-1}$ (BBCH 52). Each year, winter oilseed rape of double-low variety 'SY Kolumb' was sown in the second half of August at 60 dressed (thiuram) seeds $\mathrm{m}^{-2}$, with inter-row spacing of approx. $19 \mathrm{~cm}$. Weeds, diseases and pests were controlled throughout the growing season in accordance with integrated pest management (IPM) principles. Winter oilseed rape was harvested at physiological maturity using a small-plot harvester. Each year, winter rapeseed was harvested in the first half of July.

\section{Yield components and seed yield}

The major yield components were measured immediately before the harvest of winter oilseed crops: plants $\mathrm{m}^{-2}$, siliques plant ${ }^{-1}$, seeds silique ${ }^{-1}$, and 1000 -seed weight with $87 \%$ dry matter (DM) content. The seed yield of winter oilseed rape from each plot was determined by weight after threshing and conversion to $87 \%$ DM content.

\section{Chemical composition of seeds}

The content of macronutrients and micronutrients in the seeds of winter oilseed rape was determined on a dry weight basis. Samples of dried seeds were ground in a laboratory mill (GM 300, Retsch, Germany). Phosphorus content was determined by the vanadium-molybdenum method, $\mathrm{Ca}$ and $\mathrm{K}$ - by atomic emission spectrometry (AES) (Jenway LTD PFP 7, UK), Mg - by AAS, total $\mathrm{N}$ - by the hypochlorite method. Total S was determined turbidimetrically in plant material that had been incinerated with nitric acid and magnesium nitrate to sulfate form. 
The content of $\mathrm{Cu}, \mathrm{Zn}, \mathrm{Mn}$ and Fe was determined by Flame-AAS. Boron content was determined by the colorimetric method (UV - 1201V spectrophotometer, Shimadzu Corporation Kyoto, Japan).

\section{Processing suitability of seeds}

Seed samples were scanned in the NIR Systems 6500 monochromator (FOSS NIR Systems Inc., USA) equipped with a reflectance module. Intact seeds (approx. $5 \mathrm{~g}$ ) were placed in a standard ring cup and scanned. The results were predicted by partial least squares (PLS) calibrations established for total protein (reference data from the Kjeldahl method), crude fat (Soxhlet extraction method), ADF and NDF (van Soest's method). Glucosinolates were assayed by gas chromatography of trimethylsilyl derivatives of desulfated GLS in the Agilent 6890 gas chromatograph (Agilent Technologies Inc., USA) equipped with a 15 m HP-5 column, according to the method proposed by Raney and modified by Michalski et al. (1995). The obtained fatty acid methyl esters (FAMEs) were analyzed by gas chromatography (HP type 3390A, USA). A DB-23 capillary column (30 m in length) with an operating temperature of $200^{\circ} \mathrm{C}$ was used (injector and detector temperature was $220^{\circ} \mathrm{C}$ ), with hydrogen as carrier gas.

\section{Statistical analysis}

Data were analyzed by ANOVA, and treatment means were compared in Duncan's test at a probability level of 0.05 in Statistica 10.1 PL. Foliar application of B and experimental year were the fixed effects, and replications were the random effects. The $p$-values in fixed effect tests in ANOVA are presented in Tables 2, 3, and 4.

\section{Weather conditions}

Weather conditions (mean daily ambient temperature and daytime temperature sum) in the experimental years did not diverge from the multi-year average (1981-2010) (Table 1). Differences in precipitation levels during the spring growing season were noted between the experimental years (2012-2015). Spring precipitation covered the water demands of winter oilseed rape, determined at $220 \mathrm{~mm}$ for north-eastern Poland, only in the 2012/2013 season (Dzieżyc 1993). In the remaining growing seasons (2013/2014 and 2014/2015), precipitation levels were $21 \%$ and $31 \%$ below, respectively, the optimal values given by Dzieżyc (1993) (Table 1).

Table 1. Phenological development of winter oilseed rape, weather conditions in 2012-2015 and the multi-year average for 1981-2010

\begin{tabular}{|c|c|c|c|c|c|}
\hline \multirow[b]{2}{*}{ Parameter } & \multirow[b]{2}{*}{ Growing season } & \multicolumn{4}{|c|}{ Period } \\
\hline & & fall & $\begin{array}{c}\text { winter } \\
\text { dormancy }\end{array}$ & spring & $\begin{array}{c}\text { entire growing } \\
\text { season }\end{array}$ \\
\hline \multirow{4}{*}{$\begin{array}{l}\text { Number of } \\
\text { days }\end{array}$} & $2012 / 2013$ & 73 & 168 & 88 & 329 \\
\hline & $2013 / 2014$ & 91 & 122 & 112 & 325 \\
\hline & $2014 / 2015$ & 90 & 112 & 126 & 328 \\
\hline & 1981-2010 & 76 & 152 & 102 & 330 \\
\hline \multirow{4}{*}{$\begin{array}{l}\text { Daytime } \\
\text { temperature } \\
\operatorname{sum}\left({ }^{\circ} \mathrm{C}\right)\end{array}$} & $2012 / 2013$ & 918 & -213 & 1357 & 2062 \\
\hline & $2013 / 2014$ & 989 & 141 & 1361 & 2491 \\
\hline & $2014 / 2015$ & 1022 & 51 & 1424 & 2496 \\
\hline & 1981-2010 & 865 & -3 & 1360 & 2222 \\
\hline \multirow{4}{*}{$\begin{array}{l}\text { Mean daily } \\
\text { temperature } \\
\left({ }^{\circ} \mathrm{C}\right)\end{array}$} & $2012 / 2013$ & 12.6 & $-1,3$ & 15.4 & 6,3 \\
\hline & $2013 / 2014$ & 10.9 & 1.2 & 12.2 & 7.7 \\
\hline & $2014 / 2015$ & 11.4 & 0,5 & 11.3 & 7.6 \\
\hline & 1981-2010 & 11.4 & 0.0 & 13.3 & 6.7 \\
\hline \multirow{4}{*}{$\begin{array}{l}\text { Total } \\
\text { precipitation } \\
(\mathrm{mm})\end{array}$} & $2012 / 2013$ & 112 & 151 & 225 & 488 \\
\hline & $2013 / 2014$ & 102 & 113 & 174 & 389 \\
\hline & $2014 / 2015$ & 79 & 122 & 150 & 351 \\
\hline & 1981-2010 & 143 & 171 & 200 & 514 \\
\hline
\end{tabular}

Daytime temperature sum $\left({ }^{\circ} \mathrm{C}\right)=$ the sum of mean daily air temperatures in the analyzed period; fall = the period commencing at seeding and finishing when the mean daily air temperature drops below $5{ }^{\circ} \mathrm{C}$ for 3 consecutive days; winter dormancy = the period when the mean daily air temperature stays below $5^{\circ} \mathrm{C}$; $\operatorname{spring}=$ the period commencing when the mean daily air temperature exceeds $5^{\circ} \mathrm{C}$ for 3 consecutive days and finishing at harvest. 


\section{Results \\ Yield components and seed yield}

In this study (Haplic Luvisol, $0.5 \mathrm{mg} \mathrm{B} \mathrm{kg}^{-1}$ soil), foliar application of B at the rate of 150 and $300 \mathrm{~g} \mathrm{ha}^{-1}$ increased the seed yield of winter oilseed rape by 190 and $260 \mathrm{~kg} \mathrm{ha}^{-1}(3-4 \%)$, respectively, across experimental years (20122015) (Table 5). It should be noted that foliar application of B was more effective in years characterized by significant precipitation deficits in spring (Tables 1 and 5). In years with ample moisture conditions in spring (2012/2013), the seed yield of winter oilseed rape increased (by $0.17 \mathrm{Mg} \mathrm{ha}^{-1}$, i.e. $2 \%$ ) only in response to $300 \mathrm{~g} \mathrm{ha}^{-1}$ of foliar $\mathrm{B}$ fertilizer. The lower rate of $B$ fertilizer $\left(150 \mathrm{~g} \mathrm{ha}^{-1}\right)$ was not productive. In springs with lower precipitation levels (2013/2014 and 2014/2015), a significant increase in seed yield (by $0.30 \mathrm{Mg} \mathrm{ha}^{-1}, 4 \%$ ) was noted already at the fertilizer rate of $150 \mathrm{~g} \mathrm{~B} \mathrm{ha-1}$. During dry spells in spring, winter oilseed rape did not respond to the higher fertilizer rate of $300 \mathrm{~g} \mathrm{~B} \mathrm{ha}^{-1}$ (Tables 1 and 5). The increase in the yield of winter oilseed rape seeds in response to foliar application of $B$ resulted from the fact that the number of seeds per silique increased by $3-4 \%$.

Table 2. $P$ values $(p>F)$ in fixed effect tests for seed yield and yield components of winter oilseed rape seeds

\begin{tabular}{|c|c|c|c|}
\hline Parameter & Year & $\begin{array}{c}\text { B foliar } \\
\text { fertilization }\end{array}$ & $\begin{array}{l}\text { Year } \times \text { B foliar } \\
\text { fertilization }\end{array}$ \\
\hline Plants $\mathrm{m}^{-2}$ & $0.007^{* *}$ & $0.859 n s$ & $0.927 n s$ \\
\hline Siliques plants ${ }^{-1}$ & $<0.001 * * *$ & $0.769 n s$ & $0.804 n s$ \\
\hline Seeds silique ${ }^{-1}$ & $<0.001 * * *$ & $<0.001 * * *$ & $<0.001 * * *$ \\
\hline 1000-seed weight (g, 87\% DM) & $<0.001 * * *$ & $0.336 n s$ & $0.134 n s$ \\
\hline Seed yield (Mg ha-1 $87 \% \mathrm{DM})$ & $<0.001 * * *$ & $<0.001 * * *$ & $0.011^{*}$ \\
\hline
\end{tabular}

Table 3. $P$ values $(p>F)$ in fixed effect tests for the nutrient content of winter oilseed rape seeds

\begin{tabular}{lccc}
\hline Parameter & Year & $\begin{array}{c}\text { B foliar } \\
\text { fertilization }\end{array}$ & $\begin{array}{c}\text { Year } \times \text { B foliar } \\
\text { fertilization }\end{array}$ \\
\hline $\mathrm{B}$ & $0.071 n s$ & $0.002^{* *}$ & $0.004^{* *}$ \\
$\mathrm{Cu}$ & $1.000 n s$ & $0.465 n s$ & $0.541 n s$ \\
$\mathrm{Zn}$ & $<0.001^{* * *}$ & $<0.001^{* * *}$ & $0.085 n s$ \\
$\mathrm{Mn}$ & $0.280 n s$ & $0.407 n s$ & $0.126 n s$ \\
$\mathrm{Fe}$ & $0.184 n s$ & $<0.001^{* * *}$ & $0.081 n s$ \\
$\mathrm{~N}$ & $0.255 n s$ & $<0.001^{* * *}$ & $0.110 n s$ \\
$\mathrm{P}$ & $0.515 n s$ & $0.760 n s$ & $0.526 n s$ \\
$\mathrm{~K}$ & $0.715 n s$ & $0.536 n s$ & $0.776 n s$ \\
$\mathrm{Ca}$ & $0.639 n s$ & $<0.001^{* * *}$ & $0.052 n s$ \\
$\mathrm{Mg}$ & $0.940 n s$ & $0.387 n s$ & $0.590 n s$ \\
$\mathrm{~S}$ & $0.670 n s$ & $0.949 n s$ & $0.994 n s$ \\
\hline $\mathrm{ns}=$ not significant; ${ }^{*}=$ significant $p<0.05 ; * *$ & significant $p<0.01 ; * * *$ & significant $p<0.001$
\end{tabular}


Table 4. $P$ values $(p>F)$ in fixed effects tests for nutritional value and feed value of winter oilseed rape seeds

\begin{tabular}{|c|c|c|c|}
\hline Parameter & Year & $\begin{array}{l}\text { B foliar } \\
\text { fertilization }\end{array}$ & $\begin{array}{c}\text { Year } \times \text { B foliar } \\
\text { fertilization }\end{array}$ \\
\hline $\begin{array}{l}\text { Crude fat content of seeds } \\
\left(\mathrm{g} \mathrm{kg}^{-1} \mathrm{DM}\right)\end{array}$ & $0.917 n s$ & $<0.001 * * *$ & $0.968 n s$ \\
\hline $\mathrm{C}_{16}(\%)$ & $0.880 n s$ & $0.364 n s$ & $0.819 n s$ \\
\hline $\mathrm{C}_{18}(\%)$ & $0.387 n s$ & $1.000 \mathrm{~ns}$ & $0.339 n s$ \\
\hline $\mathrm{C}_{18: 1}(\%)$ & $0.549 n s$ & $0.001 * *$ & $0.545 n s$ \\
\hline$C_{18: 2}(\%)$ & $0.205 n s$ & $<0.001 * * *$ & $0.916 n s$ \\
\hline $\mathrm{C}_{18: 3}(\%)$ & $0.739 n s$ & $<0.001 * * *$ & $0.389 n s$ \\
\hline $\mathrm{C}_{20: 1}(\%)$ & $0.256 n s$ & $1.000 \mathrm{~ns}$ & $0.449 n s$ \\
\hline$C_{18: 2}(\omega-6)$ & \multirow{2}{*}{$0.426 n s$} & \multirow{2}{*}{$0.022^{*}$} & \multirow{2}{*}{$0.427 n s$} \\
\hline$\overline{C_{18: 3}(\omega-3)}$ & & & \\
\hline Total saturated FAs (\%) & $0.792 n s$ & $0.454 n s$ & $0.665 n s$ \\
\hline Total MUFAs (\%) & $0.412 n s$ & $0.001 * *$ & $0.397 n s$ \\
\hline Total PUFAs (\%) & $0.633 n s$ & $<0.001 * * *$ & $0.690 n s$ \\
\hline $\begin{array}{l}\text { Total protein content of } \\
\text { seeds }\left(\mathrm{g} \mathrm{kg}^{-1} \mathrm{DM}\right)\end{array}$ & $0.677 n s$ & $<0.001 * * *$ & $0.203 n s$ \\
\hline NDF (\%) & $0.152 n s$ & $<0.001 * * *$ & $0.399 n s$ \\
\hline ADF (\%) & $0.636 n s$ & $0.001^{* *}$ & $0.841 n s$ \\
\hline $\begin{array}{l}\text { Gluconapin } \\
\text { ( } \mu \text { mol g }{ }^{-1} \text { DM seeds) }\end{array}$ & $0.418 n s$ & $0.488 n s$ & $0.392 n s$ \\
\hline $\begin{array}{l}\text { Glucobrassicanapin } \\
\text { ( } \mu \text { mol g }{ }^{-1} \text { DM seeds) }\end{array}$ & $0.703 n s$ & $0.099 n s$ & $0.984 n s$ \\
\hline $\begin{array}{l}\text { Progoitrin } \\
\text { ( } \mu \mathrm{mol} \mathrm{g}^{-1} \mathrm{DM} \text { seeds) }\end{array}$ & $0.848 n s$ & $<0.001 * * *$ & $0.439 n s$ \\
\hline $\begin{array}{l}\text { Napoleiferin } \\
\left(\mu \mathrm{mol} \mathrm{g} \mathrm{g}^{-1} \mathrm{DM} \text { seeds) }\right.\end{array}$ & $0.844 n s$ & $0.264 n s$ & $0.205 n s$ \\
\hline $\begin{array}{l}\text { Glucobrassicin } \\
\text { ( } \mu \mathrm{mol} \mathrm{g}^{-1} \mathrm{DM} \text { seeds) }\end{array}$ & $0.161 n s$ & $0.919 n s$ & $0.105 n s$ \\
\hline $\begin{array}{l}\text { 4-OH-glucobrassicin } \\
\text { ( } \mu \mathrm{mol} \mathrm{g} \mathrm{g}^{-1} \mathrm{DM} \text { seeds) }\end{array}$ & $0.112 n s$ & $0.006 * *$ & $0.920 n s$ \\
\hline $\begin{array}{l}\text { Alkenyl GLS } \\
\text { ( } \mu \mathrm{mol} \mathrm{g}^{-1} \mathrm{DM} \text { seeds) }\end{array}$ & $0.781 n s$ & $<0.001 * * *$ & $0.587 n s$ \\
\hline $\begin{array}{l}\text { Indole GLS } \\
\left(\mu \mathrm{mol} \mathrm{g} \mathrm{g}^{-1} \mathrm{DM} \text { seeds }\right)\end{array}$ & $0.078 n s$ & $0.008^{* *}$ & $0.796 n s$ \\
\hline$\frac{\text { Alkenyl GLS }}{\text { Indole GLS }}$ & $0.414 n s$ & $<0.001 * * *$ & $0.343 n s$ \\
\hline
\end{tabular}

ns = not significant; ${ }^{*}=$ significant $p<0.05 ;{ }^{* *}=$ significant $p<0.01 ; * * *$ significant $p<0.001 ; \mathrm{C}_{16}=$ palmitic acid; $C_{18}=$ steric acid; $C_{18: 1}=$ oleic acid; $C_{18: 2}=$ linoleic acid; $C_{18: 3}=$ linolenic acid; $C_{20: 1}=$ eicosanoic acid; $F A=$ fatty acids; MUFA = monounsaturated fatty acid; PUFA = polyunsaturated fatty acid; $A D F=$ acid detergent fiber; NDF = neutral detergent fiber; GLS = glucosinolates; alkenyl GLS: gluconapin, glucobrassicanapin, progoitrin; indole GLS: napoleiferin, glucobrassicin, 4-OH-glucobrassicin 
Table 5. Influence of foliar application of B on the yield components and seed yield of winter oilseed rape

\begin{tabular}{|c|c|c|c|}
\hline \multirow[b]{2}{*}{ Parameter } & \multicolumn{3}{|c|}{ Rate of B fertilization $\left(\mathrm{g} \mathrm{ha}^{-1}\right.$ ) } \\
\hline & 0 & 150 & $300(150+150)$ \\
\hline & \multicolumn{3}{|c|}{$2012 / 2013$} \\
\hline Plants $\mathrm{m}^{-2}$ & 43.7 & 43.2 & 41.8 \\
\hline Siliques plants ${ }^{-1}$ & 105.8 & 109.5 & 107.3 \\
\hline Seeds silique ${ }^{-1}$ & $30.1^{\mathrm{b}}$ & $30.1^{\mathrm{b}}$ & $31.6^{\mathrm{a}}$ \\
\hline 1000-seed weight (g, 87\% DM) & 5.67 & 5.70 & 5.69 \\
\hline \multirow[t]{2}{*}{ Seed yield (Mg ha-1 $87 \%$ DM) } & $7.16^{b}$ & $7.13^{b}$ & $7.33^{\mathrm{a}}$ \\
\hline & \multicolumn{3}{|c|}{$2013 / 2014$} \\
\hline Plants $\mathrm{m}^{-2}$ & 45.2 & 45.6 & 46.8 \\
\hline Siliques plants ${ }^{-1}$ & 150.0 & 143.6 & 139.9 \\
\hline Seeds silique ${ }^{-1}$ & $23.7^{\mathrm{b}}$ & $24.6^{a}$ & $24.5^{\mathrm{a}}$ \\
\hline 1000-seed weight (g, 87\% DM) & $5.22^{\mathrm{b}}$ & $5.41^{\mathrm{a}}$ & $5.44^{\mathrm{a}}$ \\
\hline \multirow[t]{2}{*}{ Seed yield (Mg ha $\left.{ }^{-1} 87 \% \mathrm{DM}\right)$} & $7.60^{\mathrm{b}}$ & $7.90^{\mathrm{a}}$ & $7.92^{\mathrm{a}}$ \\
\hline & \multicolumn{3}{|c|}{$2014 / 2015$} \\
\hline Plants $\mathrm{m}^{-2}$ & 39.2 & 36.8 & 35.6 \\
\hline Siliques plants ${ }^{-1}$ & 163.9 & 180.6 & 192.4 \\
\hline Seeds silique $\mathrm{e}^{-1}$ & $25.5^{\mathrm{b}}$ & $26.9^{a}$ & $26.7^{\mathrm{a}}$ \\
\hline 1000-seed weight (g, 87\% DM) & 4.48 & 4.33 & 4.47 \\
\hline \multirow{2}{*}{ Seed yield (Mg ha-1 $87 \% \mathrm{DM}$ ) } & $6.63^{b}$ & $6.93^{a}$ & $6.93^{a}$ \\
\hline & \multicolumn{3}{|c|}{ across years (2012-2015) } \\
\hline Plants $\mathrm{m}^{-2}$ & 42.7 & 41.9 & 41.4 \\
\hline Siliques plants ${ }^{-1}$ & 127.2 & 135.0 & 129.6 \\
\hline Seeds silique ${ }^{-1}$ & $26.4^{\mathrm{b}}$ & $27.2^{\mathrm{a}}$ & $27.5^{\mathrm{a}}$ \\
\hline 1000-seed weight (g, 87\% DM) & 5.13 & 5.15 & 5.20 \\
\hline Seed yield (Mg ha-1 $87 \%$ DM) & $7.13^{b}$ & $7.32^{\mathrm{a}}$ & $7.39^{a}$ \\
\hline
\end{tabular}

\section{Chemical composition of seeds}

In the present study, foliar application of $B$ to winter oilseed rape in the budding stage significantly affected the content of macronutrients and micronutrients in seeds. Foliar application of $B$ at 150 and $300 \mathrm{~g} \mathrm{ha}^{-1}$ significantly increased $B$ content by 0.5 and $0.8 \mathrm{mg} \mathrm{kg}^{-1} \mathrm{DM}(6-9 \%)$ and decreased $\mathrm{Zn}$ and Fe levels by $1.7-2.9 \mathrm{mg} \mathrm{kg}^{-1} \mathrm{DM}$ (5-9\%) and 5.1-7.7 $\mathrm{mg} \mathrm{kg}^{-1} \mathrm{DM}(7-10 \%)$, respectively (Table 6). Foliar application of B significantly increased the $\mathrm{N}$ and $\mathrm{Ca}$ content of seeds by $3.5-5.5 \mathrm{~g} \mathrm{~kg}^{-1} \mathrm{DM}(15-23 \%)$ and $1.0-1.1 \mathrm{~g} \mathrm{~kg}^{-1} \mathrm{DM}(21-23 \%)$, respectively. The content of other macronutrients $(\mathrm{P}, \mathrm{K}, \mathrm{Mg}$, and $\mathrm{S})$ in the seeds of winter oilseed rape was not significantly influenced by $\mathrm{B}$ fertilization at 150 and $300 \mathrm{~g} \mathrm{ha}^{-1}$ (Table 6).

\section{Nutritional value and feed value of winter oilseed rape seeds}

In this study, B fertilization increased the crude fat content of winter oilseed rape seeds (Table 7), but a significant increase in crude fat accumulation (by 26.1-31.3 g kg-1 DM) was noted only in response to the highest rate of $B$ fertilizer ( $\left.300 \mathrm{~g} \mathrm{ha}^{-1}\right)$. The lower rate of $B\left(150 \mathrm{~g} \mathrm{ha}^{-1}\right)$ did not exert a significant effect on the biosynthesis of crude fat in the seeds of winter oilseed rape (Table 7). 
Table 6. The effect of foliar B fertilization on the nutrient content of seeds of winter oilseed rape (across years)

\begin{tabular}{lccc}
\hline & \multicolumn{3}{c}{ Rate of B fertilization $\left(\mathrm{g} \mathrm{ha}{ }^{-1}\right)$} \\
\cline { 2 - 4 } Parameter & \multicolumn{2}{c}{ Micronutrient content of seeds $\left(\mathrm{mg} \mathrm{kg}^{-1}\right)$} \\
\cline { 2 - 4 } $\mathrm{B}$ & $8.6^{\mathrm{b}}$ & $9.1^{\mathrm{a}}$ & $9.4^{\mathrm{a}}$ \\
$\mathrm{Cu}$ & 2.7 & 2.8 & 2.7 \\
$\mathrm{Zn}$ & $31.5^{\mathrm{a}}$ & $29.8^{\mathrm{b}}$ & $28.6^{\mathrm{c}}$ \\
$\mathrm{Mn}$ & 31.6 & 30.7 & 30.3 \\
$\mathrm{Fe}$ & $74.9^{\mathrm{a}}$ & $69.8^{\mathrm{b}}$ & $67.2^{\mathrm{b}}$ \\
& $\mathrm{Macronutrient}$ content of seeds $\left(\mathrm{g} \mathrm{kg}^{-1}\right)$ \\
$\mathrm{N}$ & $24.1^{\mathrm{c}}$ & $27.6^{\mathrm{b}}$ & $29.6^{\mathrm{a}}$ \\
$\mathrm{P}$ & 5.3 & 5.6 & 5.4 \\
$\mathrm{~K}$ & 8.4 & 8.2 & 8.4 \\
$\mathrm{Ca}$ & $4.8^{\mathrm{b}}$ & $5.8^{\mathrm{a}}$ & $5.9^{\mathrm{a}}$ \\
$\mathrm{Mg}$ & 2.9 & 3.0 & 3.0 \\
$\mathrm{~S}$ & 2.8 & 2.8 & 2.9 \\
\hline
\end{tabular}

Values marked with the same letter do not differ significantly at $p \leq 0.05$

Table 7. Influence of foliar application of B on the nutritional value of seeds of winter oilseed rape (across years)

\begin{tabular}{|c|c|c|c|}
\hline \multirow[b]{2}{*}{ Parameter } & \multicolumn{3}{|c|}{ Rate of $\mathrm{B}$ fertilization $\left(\mathrm{g} \mathrm{ha}^{-1}\right.$ ) } \\
\hline & 0 & 150 & $300(150+150)$ \\
\hline & & fat cont & f seeds \\
\hline \multirow[t]{2}{*}{$\mathrm{g} \mathrm{kg}^{-1} \mathrm{DM}$} & $506.1^{\mathrm{b}}$ & $500.9^{b}$ & $532.2^{\mathrm{a}}$ \\
\hline & \multicolumn{3}{|c|}{ Fatty acid concentrations of oil } \\
\hline $\mathrm{C}_{16}(\%)$ & 4.9 & 5.1 & 5.1 \\
\hline $\mathrm{C}_{18}(\%)$ & 1.6 & 1.6 & 1.6 \\
\hline $\mathrm{C}_{18: 1}(\%)$ & $63.2^{\mathrm{a}}$ & $62.1^{\mathrm{a}}$ & $60.7^{b}$ \\
\hline $\mathrm{C}_{18: 2}(\%)$ & $18.2^{\mathrm{b}}$ & $18.4^{\mathrm{b}}$ & $19.5^{\mathrm{a}}$ \\
\hline $\mathrm{C}_{18: 3}(\%)$ & $10.8^{b}$ & $11.5^{\mathrm{a}}$ & $11.8^{\mathrm{a}}$ \\
\hline$C_{20: 1}(\%)$ & 1.3 & 1.3 & 1.3 \\
\hline$\frac{C_{18: 2}(\omega-6)}{C_{18: 3}(\omega-3)}$ & $1.69^{a}$ & $1.60^{\mathrm{b}}$ & $1.65^{\mathrm{ab}}$ \\
\hline Total saturated FAs (\%) & 6.5 & 6.7 & 6.7 \\
\hline Total MUFAs (\%) & $64.5^{a}$ & $63.4^{\mathrm{b}}$ & $62.0^{c}$ \\
\hline Total PUFAs (\%) & $29.0^{c}$ & $29.9^{b}$ & $31.3^{\mathrm{a}}$ \\
\hline
\end{tabular}

Values marked with the same letter do not differ significantly at $p \leq 0.05 ; C_{16}=$ palmitic acid; $C_{18}=$ steric acid; $C_{18: 1}=$ oleic acid; $C_{18: 2}=$ linoleic acid; $C_{18: 3}=$ linolenic acid; $C_{20: 1}=$ eicosanoic acid; $F A=$ fatty acids; MUFA = monounsaturated fatty acid; PUFA = polyunsaturated fatty acid

Foliar fertilization with $B$ changed the proportions of fatty acids $C_{18: 1} C_{18: 2}$ and $C_{18: 3}$ in the seeds of winter oilseed rape. The extent of those changes was determined by the rate of $B$ fertilization. Foliar application of $B$ at $300 \mathrm{~g}$ $\mathrm{ha}^{-1}$ led to a significant decrease in oleic acid levels and an increase in linoleic acid levels. The concentrations of the above fatty acids were not significantly differentiated in response to the lower $\mathrm{B}$ rate of $150 \mathrm{~g} \mathrm{ha}^{-1}$. The linolenic acid concentrations of oil increased significantly when B was applied at $150 \mathrm{~g} \mathrm{ha}^{-1}$. The lower fertilization rate induced a minor but statistically significant decrease in the ratio of nutritionally important $\omega-6\left(C_{18: 2}\right)$ to $\omega-3$ $\left(C_{18: 3}\right)$ fatty acids (from 1.7 to 1.6). In general, higher foliar supply of B decreased MUFA levels (by 1.1-2.5\%) and increased PUFA levels (by 1.0-2.3\%) in the oil of winter oilseed rape. The noted changes were exacerbated with an increase in the rate of B fertilization. Significant differences in the concentrations of saturated FAs in oil were not observed in response to foliar B fertilization (Table 7). 
Table 8. Influence of foliar application of B on the feed value of the seeds of winter oilseed rape (across years)

\begin{tabular}{|c|c|c|c|}
\hline \multirow[b]{2}{*}{ Parameter } & \multicolumn{3}{|c|}{ Rate of B fertilization ( $\mathrm{g} \mathrm{ha} \mathrm{a}^{-1}$ ) } \\
\hline & 0 & 150 & $300(150+150)$ \\
\hline & & otein cc & eeds \\
\hline \multirow[t]{2}{*}{$\mathrm{g} \mathrm{kg}^{-1} \mathrm{DM}$} & $233.5^{b}$ & $232.3^{\mathrm{b}}$ & $242.3^{a}$ \\
\hline & \multicolumn{3}{|c|}{ Concentrations of ADF and NDF } \\
\hline NDF (\%) & $22.1^{b}$ & $21.7^{b}$ & $22.9^{a}$ \\
\hline \multirow[t]{2}{*}{ ADF (\%) } & $27.6^{b}$ & $27.2^{\mathrm{b}}$ & $28.4^{a}$ \\
\hline & \multicolumn{3}{|c|}{ GLS content $\left(\mu \mathrm{mol} \mathrm{g}{ }^{-1}\right)$ of seeds } \\
\hline Gluconapin & 1.31 & 1.32 & 1.36 \\
\hline Glucobrassicanapin & 0.30 & 0.30 & 0.40 \\
\hline Progoitrin & $4.39^{b}$ & $4.25^{b}$ & $5.60^{a}$ \\
\hline Napoleiferin & 0.09 & 0.10 & 0.10 \\
\hline Glucobrassicin & 0.19 & 0.19 & 0.19 \\
\hline 4-OH-glucobrassicin & $3.42^{a}$ & $3.09^{b}$ & $3.00^{\mathrm{b}}$ \\
\hline Alkenyl GLS & $6.00^{\mathrm{b}}$ & $5.88^{\mathrm{b}}$ & $7.35^{\mathrm{a}}$ \\
\hline Indole GLS & $3.70^{\mathrm{a}}$ & $3.38^{b}$ & $3.29^{b}$ \\
\hline$\frac{\text { Alkenyl GLS }}{\text { Indole GLS }}$ & $1.6^{b}$ & $1.7^{\mathrm{b}}$ & $2.2^{\mathrm{a}}$ \\
\hline
\end{tabular}

Values marked with the same letter do not differ significantly at $p \leq 0.05 ; A D F=$ acid detergent fiber; NDF = neutral detergent fiber; GLS = glucosinolates; alkenyl GLS: gluconapin, glucobrassicanapin, progoitrin; indole GLS: napoleiferin, glucobrassicin, 4-OH-glucobrassicin

In this study, foliar application of B enhanced total protein synthesis in the seeds of winter oilseed rape. It should be noted, however, that a significant increase in the total protein content of seeds (by around $8.8 \mathrm{~g} \mathrm{~kg}^{-1} \mathrm{DM}$ ) was observed only in response to the highest rate of $\mathrm{B}$ fertilizer $\left(300 \mathrm{~g} \mathrm{ha}^{-1}\right)$. The highest fertilizer rate also induced a significant increase in ADF and NDF levels (Table 8).

Foliar application of B to winter oilseed rape led to changes in the content and structure of GLS which reduced the feed value of fat-free seed residues. Boron fertilization significantly increased progoitrin content (by 28-32\%) and decreased 4-OH-glucobrassicin content (by 10-12\%). It should also be noted that the levels of alkenyl GLS increased only in response to the highest rate of $\mathrm{B}$ fertilizer at $300 \mathrm{~g} \mathrm{~B} \mathrm{ha}^{-1}$, whereas the content of indole GLS decreased already under the influence of $150 \mathrm{~g} \mathrm{~B} \mathrm{ha}^{-1}$. Those changes increased the ratio of alkenyl GLS to indole GLS (Table 8), which lowered the feed value of winter oilseed rape.

\section{Discussion}

\section{Yield components and seed yield}

Boron fertilization of Luvisols containing $0.1-0.8 \mathrm{mg} \mathrm{B} \mathrm{kg}^{-1}$ usually increases the seed yield of rapeseed by up to 10-15\%. Malhi et al. (2003) demonstrated that the seed yield of B. rapa and B. napus (canola type) grown in central Canada increased only in response to soil application of $B$ at the rate of $2 \mathrm{~kg} \mathrm{~B} \mathrm{ha}^{-1}$. A reduction in the rate of $B$ soil fertilizer $\left(1 \mathrm{~kg} \mathrm{ha}^{-1}\right)$ or replacement of soil fertilization with foliar application of $\mathrm{B}\left(250\right.$ and $\left.500 \mathrm{~g} \mathrm{ha}^{-1}\right) \mathrm{did}$ not lead to a significant increase in yield relative to control (without $B$ fertilization). In a study conducted in eastern Canada, Ma et al. (2015) reported a 7-13\% increase in the seed yield of B. napus only after foliar application of B at $500 \mathrm{~g} \mathrm{ha}^{-1}$, whereas soil fertilization with $2 \mathrm{~kg} \mathrm{~B} \mathrm{ha}^{-1}$ did not increase seed yield. In south-western Iran, the highest seed yield of rapeseed plants grown on calcareous soil with an available B content of $0.29 \mathrm{mg} \mathrm{kg}^{-1}$ was noted in response to soil fertilization with $2.5 \mathrm{~kg} \mathrm{~B} \mathrm{ha}^{-1}$. Despite the above, the reported increase in seed yield did not exceed $10 \%$ relative to control (without B fertilization) (Nadian et al. 2010). In a study conducted by Krauze et al. (1991) in north-eastern Poland on Podzolic soils containing $0.12-0.25 \mathrm{mg} \mathrm{B} \mathrm{kg}^{-1}$ (low abundance), foliar application of B at the rate of 200 and $400 \mathrm{mg} \mathrm{ha}^{-1}$ increased the seed yield of winter oilseed rape by 0.38 and $0.51 \mathrm{Mg} \mathrm{ha}^{-1}(7-8 \%)$, respectively. A further rise in seed yield was not observed when the rate of B fertilizer was increased to $800 \mathrm{~g}$ ha $^{-1}$ (Krauze et al. 1991). In the experiment carried out by Sienkiewicz-Cholewa and Kieloch (2015) in western and 
southern Poland, the application of B fertilizer at $2 \mathrm{~kg} \mathrm{ha}^{-1}$ to light soils (loamy sand) with moderate and high B levels increased the seed yield of winter oilseed rape by $0.19-0.45 \mathrm{Mg} \mathrm{ha}^{-1}(5-14 \%)$. In the present experiment, established on Haplic Luvisol with moderate B levels, foliar application of B increased the seed yield of winter oilseed rape by $3 \%$ (150 g B ha-1) to $4 \%$ (300 $\mathrm{g} \mathrm{B} \mathrm{ha}^{-1}$ ) (Table 5). In the work of Krauze et al. (1991), foliar application of $B$ induced a greater increase in the seed yield of winter oilseed rape when precipitation levels in spring were low. Our findings also indicate that foliar application of B to winter oilseed rape exerts a greater effect on seed yield when rainfall amounts are low during the spring growing season (Table 5).

In soils that are deficient in nutrients, including B, foliar application of B can increase the seed yield of rapeseed crops by even several dozen percent. In a study by Varenyiova and Ducsay (2014), foliar application of B at 200, 400 and $800 \mathrm{~g} \mathrm{~B} \mathrm{ha}^{-1}$ in Slovakia (brown Podzolic soils) increased the seed yield of winter oilseed rape by $31 \%$, $42 \%$ and $48 \%$, respectively. In central China, the seed yield of rapeseed grown on sandy soils with a low B content $\left(0.06 \mathrm{mg} \mathrm{kg}^{-1}\right)$ increased by $67 \%$ in response to foliar application of $\mathrm{B}$ and $\mathrm{Mo}$, by $55 \%$ in response to foliar application of $\mathrm{B}$ and $\mathrm{Zn}$, and by $68 \%$ in response to foliar application of $\mathrm{B}, \mathrm{M}$ and $\mathrm{Zn}$. The application of Mo and $\mathrm{Zn}$ only increased seed yield by $38 \%$ (Yang et al. 2009).

Higher seed yield in response to foliar application of B can be attributed to the micronutrient's positive effect on seed production in siliques and, to a lesser extent, on 1000-seed weight (Yang et al. 2009, Table 5).

\section{Chemical composition of seeds}

The uptake and accumulation of micronutrients in various parts of crop plants (roots, shoots, seeds) are determined by the humus content of soil, the activity of microorganisms in the rhizosphere, soil pH, soil moisture content (Grzebisz 2008, Hänsch and Mendel 2009) and fertilization (Jankowski et al. 2014). Boron fertilization increases the B content of developing B. napus seeds (14 days after flowering) (Eggert and Wirén 2016). Boron content decreases in successive stages of seed development, which can be attributed to the dilution effect because seed weight increases during that period (Eggert and Wirén 2016). In most cases, the B content of fully ripe seeds is higher when B fertilizers are applied (Malhi et al. 2003). Similar results were noted in the present study (Table 6). Foliar application of B at 150-300 $\mathrm{g} \mathrm{B} \mathrm{ha}^{-1}$ increased the B content of seeds of winter oilseed rape grown on soils with moderate $B$ levels by $6-9 \%$ (Table 6). In a Canadian experiment, the highest increase (by $17 \%$ ) in the B content of $B$. rapa and $B$. napus seeds was reported when $B$ was applied to soil at $2 \mathrm{~kg} \mathrm{~B} \mathrm{ha-1}$. The remaining fertilization regimes (foliar and seed row) and rates (250 and $500 \mathrm{~g} \mathrm{~B} \mathrm{ha}^{-1} ; 0.5,1.0,2.0 \mathrm{~kg} \mathrm{~B} \mathrm{ha}^{-1}$ ) induced a smaller (2-6\%) but significant increase in the B content of seeds of Brassica crops (Malhi et al. 2003). In a study by Krauze et al. (1991), foliar application of B at the rate of 200,400 and $800 \mathrm{~g} \mathrm{ha}^{-1}$ increased the B content of seeds of winter oilseed rape by $36 \%, 46 \%$ and $63 \%$, respectively. In the work of Bowszys (2001), the B content of seeds increased by $3.2 \mathrm{mg} \mathrm{kg}^{-1} \mathrm{DM}$ (by 23\%) during bud formation in winter oilseed rape plants in response to higher rates of foliar $\mathrm{B}$ fertilizer $\left(400,600,800\right.$ and $\left.1200 \mathrm{~g} \mathrm{ha}^{-1}\right)$.

Boron fertilization of winter oilseed rape also induces changes in the macronutrient content of seeds (Krauze et al. 1991, Bowszys 2001, Table 6). The above can be attributed to the significant role played by B in the growth and differentiation of plant tissues, cell membrane function, enzyme activity control, carbohydrate transformations (Matoh 1997), nitrogen availability and transformation (Ruiz et al. 1998). Boron is accumulated mainly in cell walls and undergoes the same transport mechanisms in plants as Ca (Grzebisz 2008). In this study, foliar application of $\mathrm{B}$ significantly increased the $\mathrm{N}$ and Ca content of seeds by $3.5-5.5 \mathrm{~g} \mathrm{~kg}^{-1} \mathrm{DM}$ and $1.0-1.1 \mathrm{~g} \mathrm{~kg}^{-1} \mathrm{DM}$, respectively (Table 6). In the experiment conducted by Krauze et al. (1991), the $\mathrm{N}$ and K content of seeds of winter oilseed rape also peaked (increase by 1.2 and $1.0 \mathrm{~g} \mathrm{~kg}^{-1} \mathrm{DM}$, respectively, relative to control) in response to the highest rate of B fertilization. In a study by Bowszys (2001), foliar application of B to budding plants of winter oilseed rape contributed to a significant increase in the $\mathrm{Mg}, \mathrm{P}$ and $\mathrm{K}$ content of seeds by $2.0,0.5$ and $0.3 \mathrm{~g} \mathrm{~kg}^{-1} \mathrm{DM}$, respectively.

\section{Nutritional value and feed value of winter oilseed rape seeds}

In our study, foliar application of B at $300 \mathrm{~g} \mathrm{ha}^{-1}$ significantly increased the crude fat content of winter oilseed rape seeds, whereas the lower rate of $\mathrm{B}\left(150 \mathrm{~g} \mathrm{ha}^{-1}\right)$ did not exert such an effect (Table 7). It should be noted, however, that the biosynthesis of fatty acids in rapeseed is largely determined by temperature during flowering and seed ripening (Wójtowicz 2013). This observation could explain why many authors reported a negative influence of $B$ fertilization on crude fat levels in rapeseed. In studies by Karamanos et al. (2003) and Nadian et al. (2010), crude fat concentrations in the seeds of B. napus were not correlated with B fertilization. In the work of Bowszys (2001), foliar application of $B\left(\right.$ at $400,600,800$, and $1200 \mathrm{~g} \mathrm{ha}^{-1}$ ) decreased crude fat levels in the seeds of winter oilseed rape by $23 \mathrm{~g} \mathrm{~kg}^{-1}$ DM. Öztürk et al. (2010) reported that the application of B fertilizer to soil reduced the crude fat 
content of seeds of spring oilseed rape by around $38 \mathrm{~g} \mathrm{~kg}^{-1} \mathrm{DM}$ on average. In the work of Krauze et al. (1991), foliar application of B at $400 \mathrm{~g} \mathrm{~B} \mathrm{ha}^{-1}$ increased crude fat levels by $6.4 \mathrm{~g} \mathrm{~kg}^{-1} \mathrm{DM}$ in the seeds of winter oilseed rape. Malhi et al. (2003) reported that foliar application of $B$ at the rate of $500 \mathrm{~g} \mathrm{ha}^{-1}$ increased crude fat concentrations in the seeds of $B$. napus and $B$. rapa by approximately $14 \mathrm{~g} \mathrm{~kg}^{-1} \mathrm{DM}$.

Boron fertilization influences the fatty acid profile of Brassica crops (Krauze et al. 1991, Bowszys 2001, Yang et al. 2009, Table 7). In the present study, foliar fertilization with B decreased MUFA levels (by 1.1-2.5\%) and increased PUFA levels (by 1.0-2.3\%) in the oil of winter oilseed rape. The content of saturated FAs in oil did not change significantly in response to foliar B fertilization (Table 7). Krauze et al. (1991) reported a higher concentrations of $\mathrm{C}_{16}, \mathrm{C}_{18: 1}, \mathrm{C}_{18: 2}$ and a lower concentrations of $\mathrm{C}_{22: 1}$ in rapeseed fertilized with $\mathrm{B}$ at the rate of $400 \mathrm{~g} \mathrm{ha}^{-1}$. A significant (12-14\%) decrease in the erucic acid concentrations of rapeseed in response to foliar application of $B$, $B+M o$ and B + Zn was noted by Yang et al. (2009). In the experiment conducted by Bowszys (2001), the application of foliar $B$ fertilizer resulted in higher levels of MUFAs $\left(C_{18: 1}\right)$ and PUFAs $\left(C_{18: 2}\right.$ and $\left.C_{18: 3}\right)$, and lower concentrations of saturated FAs $\left(\mathrm{C}_{16}\right.$ and $\left.\mathrm{C}_{18}\right)$ in winter oilseed rape.

Boron fertilization can exert varied effects on the total protein content of rapeseed (Bowszys 2001, Malhi et al. 2003, Nadian et al. 2010, Öztürk et al. 2010, Table 8). In Central Canada (Malhi et al. 2003) and south-western Iran (Nadian et al. 2010), B fertilization did not influence the total protein content of seeds in Brassica crops. In a study carried out by Öztürk et al. (2010) in the Central Anatolia Region of Turkey, B fertilizer applied to soil lowered the total protein content of seeds of spring oilseed rape by $21.4 \mathrm{~g} \mathrm{~kg}^{-1} \mathrm{DM}$ on average. Foliar application of $\mathrm{B}$ to winter oilseed rape in north-eastern Poland increased the total protein content of seeds by $18 \mathrm{~g} \mathrm{~kg}^{-1} \mathrm{DM}$ (Bowszys 2001). In the present study, foliar application of $B$ at the highest rate $\left(300 \mathrm{~g} \mathrm{ha}^{-1}\right)$ contributed to total protein

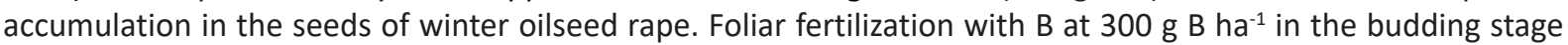
also induced a significant increase in ADF and NDF levels (Table 8), which negatively affected the feed value of fat-free seed residues because increased ADF content decreases nutrient digestibility and increased NDF content impairs feed conversion (Bell 1993).

Glucosinolates are lipophilic compounds which easily penetrate cell membranes. They can suppress the growth and reproduction of animals, and interfere with iodine metabolism. Glucosinolates negatively affect cardiovascular health, contribute to liver and kidney failure, and cause bronchitis, pneumonia and diarrhea. The antinutritional properties of GLS can be attributed to the most active isothiocyanate derivative which is released during the hydrolysis of alkenyl GLS with the highly goitrogenic 5-vinyloxasolidine-2-thione. Its goitrogenic effects result from inhibited iodination of tyrosine, which leads to hyperthyroidism (Verkerk et al. 2009). For this reason, a high content of alkenyl GLS limits the feed value of seeds (oil cake, meal) of crops from the family Brassicaceae. The GLS content of seeds is one of the main criteria during the registration and introduction of double-low varieties of rapeseed to the EU market. However, recent research has demonstrated that GLS degradation products, isothiocyanates (ITC) and indole compounds, have anti-carcinogenic properties and may deliver health benefits to humans and animals (Verkerk et al. 2009). In a study by Yang et al. (2009), B fertilization lowered the GLS content of rapeseed from $19.9 \mathrm{~g} \mathrm{~mol} \mathrm{~kg}^{-1}$ in control treatments to $16.1 \mathrm{~mol} \mathrm{~kg}^{-1}$ in fertilized treatments. The application of Mo and Zn fertilizers induced a much smaller reduction in GLS levels (to 18.4 and $18.5 \mathrm{~mol} \mathrm{~kg}^{-1}$, respectively). In the present study, B fertilization significantly increased the content of alkenyl GLS (mainly progoitrin) and decreased the content of indole GLS (mainly 4-OH-glucobrassicin) in the seeds of winter oilseed rape (Table 8). It should be stressed that foliar application of B increased the content of alkenyl GLS, antinutritional factors, which however did not exceed the maximum allowable level of $25 \mu \mathrm{mol} \mathrm{g}^{-1}$ 91\% DM seeds set for the European Union (EC 1999).

\section{Conclusion}

Foliar application of $\mathrm{B}$ at the beginning of bud formation in winter oilseed rape increased seed yield by 0.17 to $0.30 \mathrm{Mg} \mathrm{ha}^{-1}$. Boron fertilization was more effective in increasing seed yield during dry spells in spring. The observed increase in the yield of winter oilseed rape seeds in response to foliar application of $B$ can be attributed to this micronutrient's positive influence on seed production in siliques (the number of seeds per silique increased by around $4 \%$ ).

Foliar fertilization with B increased B content by $0.5-0.8 \mathrm{mg} \mathrm{kg}^{-1} \mathrm{DM}$ and decreased $\mathrm{Zn}$ and Fe levels in the seeds of winter oilseed rape by 1.7-2.9 and 5.1-7.7 $\mathrm{mg} \mathrm{kg}^{-1} \mathrm{DM}$, respectively. When B fertilizer was applied at the rate of 150-300 g B ha-1, the $\mathrm{N}$ and Ca content of the evaluated seeds increased by 3.5-5.5 and 1.0-1.1 g kg-1 DM, respectively. 
Foliar fertilization with $B$ had a beneficial influence on the nutritional value of winter oilseed rape seeds. Foliar application of $\mathrm{B}$ at $300 \mathrm{~g} \mathrm{~B} \mathrm{ha}^{-1}$ increased the crude fat content of seeds (by around 26.1-31.3 $\mathrm{g} \mathrm{kg}^{-1} \mathrm{DM}$ ), decreased oleic acid levels and increased the concentrations of linoleic acid and linolenic acid. At the higher rate, $B$ fertilizer lowered the percentages of MUFAs and PUFAs in oil.

The total protein content of seeds increased (by around $8.8 \mathrm{~g} \mathrm{~kg}^{-1} \mathrm{DM}$ ) in response to foliar fertilization with $\mathrm{B}$ at $300 \mathrm{~g} \mathrm{~B} \mathrm{ha}^{-1}$. The above rate of $B$ fertilization led to a significant increase in the concentrations of ADF and NDF. Foliar application of B significantly increased the content of alkenyl GLS (progoitrin) and decreased the content of indole GLS (4-OH-glucobrassicin), thus deteriorating the feed value of winter oilseed rape seeds.

\section{Acknowledgements}

The results presented in this paper were obtained as part of a comprehensive study financed by the University of Warmia and Mazury in Olsztyn and Kazgod Ltd. in Błonie (Project No. 20.610.020-300 and 20.690.010-500).

\section{References}

Bell, J.M. 1993. Factors affecting the nutritional value of canola meal: A review. Canadian Journal of Animal Science 73: 619-697.

Bowszys, T. 2001. Działanie boru w nawożeniu rzepaku ozimego (Brassica napus L.) i szarłatu uprawnego (Amaranthus cruentus L.). University Publisher University Warmia and Mazury in Olsztyn, Poland: Dissertations and Monographs. 75 p. (in Polish).

Brown, P.H., Bellaloui, N., Wimmer, M.A., Bassil, E.S., Ruiz, J., Hu, H., Pfeffer, H., Dannel, F. \& Romheld, V. 2002. Boron in plant biology. Plant Biology 4: 205-223.

Camacho-Cristóbal, J.J., Rexach, J. \& González-Fontes, A. 2008. Boron in plants: deficiency and toxicity. Journal of Integrative Plant Biology 50: 1247-1255.

Chormova, D., Messenger, D.J. \& Fry S.C. 2014. Boron bridging of rhamnogalacturonan-II, monitored by gel electrophoresis, occurs during polysaccharide synthesis and secretion, but not post-secretion. Plant Journal 77: 534-546.

Deora, A., Gossen, B.D., Hwang, S.F., Pageau, D., Howard, R.J., Walley, F. \& McDonald, M.R. 2014. Effect of boron on clubroot of canola in organic and mineral soils and on residual toxicity to rotational crops. Canadian Journal of Plant Science 94: 109-118.

Dzieżyc, J. 1993. Czynniki plonotwórcze - plonowanie roślin. Warszawa-Wrocław, Poland: Państwowe Wydawnictwo Naukowe. 475 p. (in Polish).

EC 1999. Legislation 280. Official Journal of European Communities. Vol. 42, 30 October 1999. http://eur-lex.europa.eu/legalcontent/EN/TXT/PDF/ ?uri=CELEX:31999R2316\&from=EN. Accessed 11 March 2016.

Eggert, K. \& von Wirén, N. 2016. The role of boron nutrition in seed vigour of oilseed rape (Brassica napus L.). Plant and Soil 402: $63-76$.

FAOSTAT 2016. Faostat Agriculture data. http://www.apps.fao.org. Accessed 11 March 2016.

Glover, J.G., Reganold, J.P., Bell, L.W., Borevitz, J., Brummer, E.C., Buckler, E.S., Cox, C.M., Cox, T.S., Crews, T.E., Culman, S.W., DeHaan, L.R., Eriksson, D., Gill, B.S., Holland, J., Hu, F., Hulke, B.S., Ibrahim, A.M.H., Jackson, W., Jones, S.S., Murray, C., Paterson, A.H., Ploschuk, E., Sacks, E.J., Snapp, S., Tao, D., van Tassel, D.L., Wade, L.J., Wyse, D.L. \& Xu Y. 2010. Increased food and ecosystem security via perennial grains. Science 328: 1638-1639.

Grzebisz, W. 2008. Nawożenie roślin uprawnych. Part 1. Podstawy nawożenia. Poznań, Poland: Państwowe Wydawnictwo Rolnicze i Leśne. 428 p. (in Polish).

Hänsch, R. \& Mendel, R.R. 2009. Physiological functions of mineral micronutrients ( $\mathrm{Cu}, \mathrm{Zn}, \mathrm{Mn}, \mathrm{Fe}, \mathrm{Ni}, \mathrm{Mo}, \mathrm{B}, \mathrm{Cl}$ ). Current Opinion in Plant Biology 12: 259-266.

Huang, L.B., Ye, Z.Q. \& Bell R.W. 1996. The importance of sampling immature leaves for the diagnosis of boron deficiency in oilseed rape (Brassica napus cv. Eureka). Plant and Soil 183: 187-198.

IUSS Working Group WRB 2006. World reference base for soil resources 2006. World Soil Resources Reports No. 103. FAO, Rome. http://www.fao.org/3/a-a0510e.pdf. Accessed 03 March 2016.

Jankowski, K., Hulanicki, P.S., Krzebietke, S., Żarczyński, P., Hulanicki, P. \& Sokólski, M. 2016. Yield and quality of winter oilseed rape in response to different systems of foliar fertilization. Journal of Elementology 21: 1017-1027.

Jankowski, K., Kijewski, Ł., Skwierawska, M., Krzebietke, S. \& Mackiewicz-Walec, E. 2014. The effect of sulfur fertilization on the concentrations of copper, zinc and manganese in the roots, straw and cake of rapeseed (Brassica napus L. ssp. oleifera Metzg). Journal of Elementology 19: 433-446.

Jankowski, K.J., Budzyński, W.S., Kijewski, Ł. \& Zając, T. 2015. Biomass quality of Brassica oilseed crops in response to sulfur fertilization. Agronomy Journal 107: 1377-1391.

Karamanos, R.E., Goh, T.B. \& Stonehouse, T.A. 2003. Canola response to boron in Canadian prairie soils. Canadian Journal of Soil Science 83: 249-259.

Krauze, A., Bowszys, T., Bobrzecka, D. \& Rotkiewicz, D. 1991. Effect of foliar boron fertilization on the yield and quality of winter rape. In: Proceedings of the $8^{\text {th }}$ International Rapeseed Congress, 9-11 July in Saskatoon, Saskatchewan, Canada. 2-3: 547-553.

Liu, J., Yang, J., Li, R., Shi, L., Zhang, C., Long, Y., Xu, F. \& Meng, J. 2009. Analysis of genetic factors that control shoot mineral concentrations in rapeseed (Brassica napus) in different boron environments. Plant and Soil 320: 255-266. 
Ma, B.-L., Biswas, D.K., Herath, A.W., Whalen, J.K., Ruan, S.Q., Caldwell, C., Earl, H., Vanasse, A., Scott, P. \& Smith, D.L. 2015. Growth, yield, and yield components of canola as affected by nitrogen, sulfur, and boron application. Journal of Plant Nutrition and Soil Science 178: 658-670.

Malhi, S.S., Raza, M., Schoenau, J.J., Mermut, A.R., Kutcher, R., Johnston, A.M. \& Gill, K.S. 2003. Feasibility of boron fertilization for yield, seed quality and B uptake of canola in northeastern Saskatchewan. Canadian Journal of Soil Science 83: 99-108.

Matoh, T. 1997. Boron in plant cell walls. Plant and Soil 193: 59-70.

Michalski, K., Kołodziej, K. \& Krzymański, J. 1995. Quantitative analysis of glucosinolates in seeds of oilseed rape-effect of sample preparation on analytical results. In: Proceedings of the th $^{\text {th }}$ ternational Rapeseed Congress, 4-7 July in Cambridge, UK. 3: 911-913.

Nadian, H., Najarzadegan, R., Alami Saeid, K., Gharineh, M.H. \& Siadat, A. 2010. Effects of boron and sulfur application on yield and yield components of Brassica napus L. in calcareous soil. World Applied Sciences Journal 11: 89-95.

O'Neill, M.A., Ishii, T., Albersheim, P. \& Darvill, A.G. 2004. Rhamnogalacturonan II: structure and function of a borate cross-linked cell wall pectic polysaccharide. Annual Review of Plant Biology 55: 109-139.

Öztürk, Ö., Soylu, S., Ada, R., Gezgin, S. \& Babaoglu, M. 2010. Studies on differential response of spring canola cultivars to B toxicity. Journal of Plant Nutrition 33: 1141-1154.

Przybylski, R. 2011. Canola/rapeseed oil. In: Gunstone, F.D. (ed.). Vegetable oils in food technology: composition, properties and uses. Oxford, UK: Blackwell Publishing. p. 107-136.

Reid, R. 2014. Understanding the boron transport network in plants. Plant and Soil 385: 1-13.

Ruiz, J.M., Baghour, M., Bretones, G., Belakbir, A. \& Romero, L. 1998. Nitrogen metabolism in tobacco plants (Nicotiana tabacum L.): role of boron as possible regulatory factor. International Journal of Plant Sciences 159: 121-126.

Shorrocks, V.M. 1997. The occurrence and correction of boron deficiency. Plant and Soil 193: 121-148.

Sienkiewicz-Cholewa, U. 2005. Znaczenie boru i miedzi w uprawie rzepaku w kraju. Rośliny Oleiste - Oilseed Crops 26: 163-172. (in Polish).

Sienkiewicz-Cholewa, U. \& Kieloch, R. 2015. Effect of sulphur and micronutrients fertilization on yield and fat content in winter rape seeds (Brassica napus L.). Plant, Soil and Environment 61: 164-170.

Varenyiova, M. \& Ducsay, L. 2014. Effect of increasing doses of boron on oil production of oilseed rape (Brassica napus L.). In: Proceedings Conference MendelNet, 19-20 November in Brno, Czech. https://mnet.mendelu.cz/mendelnet2014/articles/ 50_varenyiova_988.pdf. Accessed 03 March 2016.

Verkerk, R., Schreiner, M., Krumbein, A., Ciska, E., Holst, B., Rowland, I., De Schrijver, R., Hansen, M., Gerhäuser, C., Mithen, R. \& Dekker, M. 2009. Glucosinolates in Brassica vegetables: the influence of the food supply chain on intake, bioavailability and human health. Molecular Nutrition and Food Research 53: 219-265.

Wang, Y.H., Shi, L., Cao, X.Y. \& Xu, F.S. 2007. Studies on plant boron nutrition and boron fertilization in China. In: Xu, F.S., Goldbach, H.E., Brown, P.H., Bell, R.W., Fujiwara, T., Hunt, C.D., Goldberg, S. \& Shi, L. (eds.). Advances in Plant and Animal Boron Nutrition. Proceedings of the $3^{\text {rd }}$ International Symposium on all Aspects of Plant and Animal Boron Nutrition. Netherlands: Springer Press. p. 93-101.

Wimmer, M.A. \& Eichert, T. 2012: Review: Mechanisms for boron deficiency-mediated changes in plant water relations. Plant Science 203-204: 25-32.

Wójtowicz, M. 2013. Rola czynników środowiskowych i agrotechnicznych w kształtowaniu ilości i jakości plonu rzepaku ozimego (Brassica napus L.). Publisher The Plant Breeding and Acclimatization Institute - National Research Institute, Radzików, Poland: Monographs and Disseratations. 111 p. (in Polish).

Xu, F.S., Wang, Y.H. \& Meng, J.L. 2001. Mapping boron efficiency gene(s) in Brassica napus using RFLP and AFLP markers. Plant Breeding 120: 319-324.

Yang, M., Shi, L., Xu, F-S., Lu, J.-W. \& Wang, Y.-H. 2009. Effects of B, Mo, Zn, and their interactions on seed yield of rapeseed (Brassica napus L.). Pedosphere 19: 53-59

Zhang, D., Zhao, H., Shi, L. \& Xu, F. 2014. Physiological and genetic responses to boron deficiency in Brassica napus: A review. Soil Science and Plant Nutrition 60: 304-313.

Zhao, Z.K., Wu, L.K., Nian, F.Z., Ding, G.D., Shi, T.X., Zhang, D.D., Shi, L., Xu, F.S. \& Meng, J.L. 2012. Dissecting quantitative trait loci for boron efficiency across multiple environments in Brassica napus. Plos One 7. http://journals. plos.org/plosone/article?id=10.1371/ journal.pone.0045215. Accessed 03 March 2016. 